\title{
Development of Auto Sanitizer for Mitigation of Covid-19 - Using Solar Powered Aluminum Structural Chamber
}

\author{
S.C. Madu ${ }^{1}$, E.A. $\mathrm{Madu}^{2}$, C.O. Anyaoha ${ }^{3}$, P.A. Okonkwo, ${ }^{4}$, U.C. Ogbuefi ${ }^{5}$, S.V. \\ Egoigwe $^{6}$, V.S. Aigbodion ${ }^{7}$ and E.C. Ejiogu ${ }^{8}$ \\ ${ }^{1,7}$ Department of Materials and Metallurgical Engineering, University of Nigeria Nsukka, NIGERIA. \\ ${ }^{2}$ Department of Molecular Genetics and Biotechnology, University of Nigeria Nsukka, NIGERIA. \\ ${ }^{3,4}$ Department of Mechanical Engineering, University of Nigeria Nsukka, NIGERIA. \\ ${ }^{5,8}$ Department of Electrical Engineering, University of Nigeria Nsukka, NIGERIA. \\ ${ }^{6}$ Department of Mechatronic Engineering, University of Nigeria Nsukka, NIGERIA. \\ ${ }_{1,3,4,5,6,7,8}$ African Centre of Excellence for Sustainable Power and Energy Development, University of Nigeria, Nsukka, NIGERIA. \\ ${ }^{7}$ Faculty of Engineering and Built Environment, University of Johannesburg, SOUTH AFRICA.
}

\begin{abstract}
The use of auto sanitizer in the disinfection of human body and surfaces against dangerous micro-organisms like coronavirus diseases that are infectious is of great importance to schools, family, community, and public health. The outbreak of novel Coronavirus in late 2019, which has crippled the academic, social, and economic activities globally is as a result of unhygienic activities of living creatures like, man, and animals. But a good number of technologies can be developed to tackle the emergence of this novel infectious virus. The challenge of COVID-19 that resulted to ill-health, high death rate, and shutdown of activities was being addressed radically by different medical practitioners, engineers through various practical innovations, methods and mitigation approach - ranging from the use offace shields and respiratory facemasks to practicing of social and physical distancing. This part of preventive measures has led us to developing an Auto Sanitizer that is made of Aluminum Chamber which does not wet the cloth or human body but disinfects it against COVID-19.
\end{abstract}

Keywords: Auto sanitizer, technologies, disinfection, COVID-19, shutdown, face shields, Aluminum, Chamber, and facemasks.

\subsection{INTRODUCTION}

Total shutdown of activities was eminent in 2020 as a result of Coronavirus which was later renamed COVID-19 and declared as a Pandemic by World Health Organization (WHO) on 11th March, 2020 as the outbreak of the virus continued to evolve [1][2]. COVID-19 is a pathogenic virus and was coined from Corona which can be seen as crown-like spikes on the outer layer of the virus [3]. It is transmittable viral infectious disease caused by severe acute respiratory syndrome coronavirus 2 (SARSCoV-2) [4]. When someone is infected by COVID-19, it firstly, enters through the mouth and nose, it then finds a "host cell" in the respiratory system, the host cell then burst and infect other cells nearby, and the person becomes sick which may lead to the cause of pulmonary failure, which can result to sudden death [4][5]. The virus

* Corresponding author (Tel: +234 (0) 7063650 014)

Email addresses: solomon.madu@unn.edu.ng (S.C. Madu), endaline.madu@unn.edu.ng (E.A. Madu),

chukwuemeka.anyaoha@unn.edu.ng (C.O. Anyaoha),

peter.okonwo@unn.edu.ng (P.A. Okonkwo),

uche.ogbuefi@unn.edu.ng (U.C. Ogbuefi),

sochima.egoigwe@unn.edu.ng (S.V. Egoigwe),

victor.aigbodion@unn.edu.ng (V.S. Aigbodion),

emenike.ejiogu@unn.edu.ng (E. C. Ejiogu) is transmitted through direct contact with respiratory droplets of an infected person (generated through coughing and sneezing) and on contaminated surface(s) when droplets of the viruses fall on the floors, or get attached to the walls or objects [6]. An individual is infected from touching a contaminated surface and touches his face (e.g., mouth, eyes, or nose). Also, an individual can be infected when he breaths in the coronavirus within a close proximity range of someone who has COVID-19. Children could easily contract the virus, show little to no symptoms, and then pass to it their parents or elderly ones at home. Hence, their protection is particularly important, and precautions are necessary to prevent the potential spread of COVID-19 in educational settings.

These infectious diseases were known to infect mainly animals until the global world experienced the outbreak of COVID-19 in Wuhan, China which has rapidly, spread across the globe, triggering unprecedented pandemic [7]. Studies show that old people with ill-health like: cardiac heart disease, hypertension, cancerous cells, or diabetes) have been discovered as potential risk factors for severe disease and sudden mortality [5]. The rapid infectious nature of the virus has resulted to the shutdown of socio-economic activities globally like; closing of 
religious activities, academic activities, entrepreneurship activities, cracking down of political activities, and global economic recession, especially, developing economy like; Sub Sahara Africa.

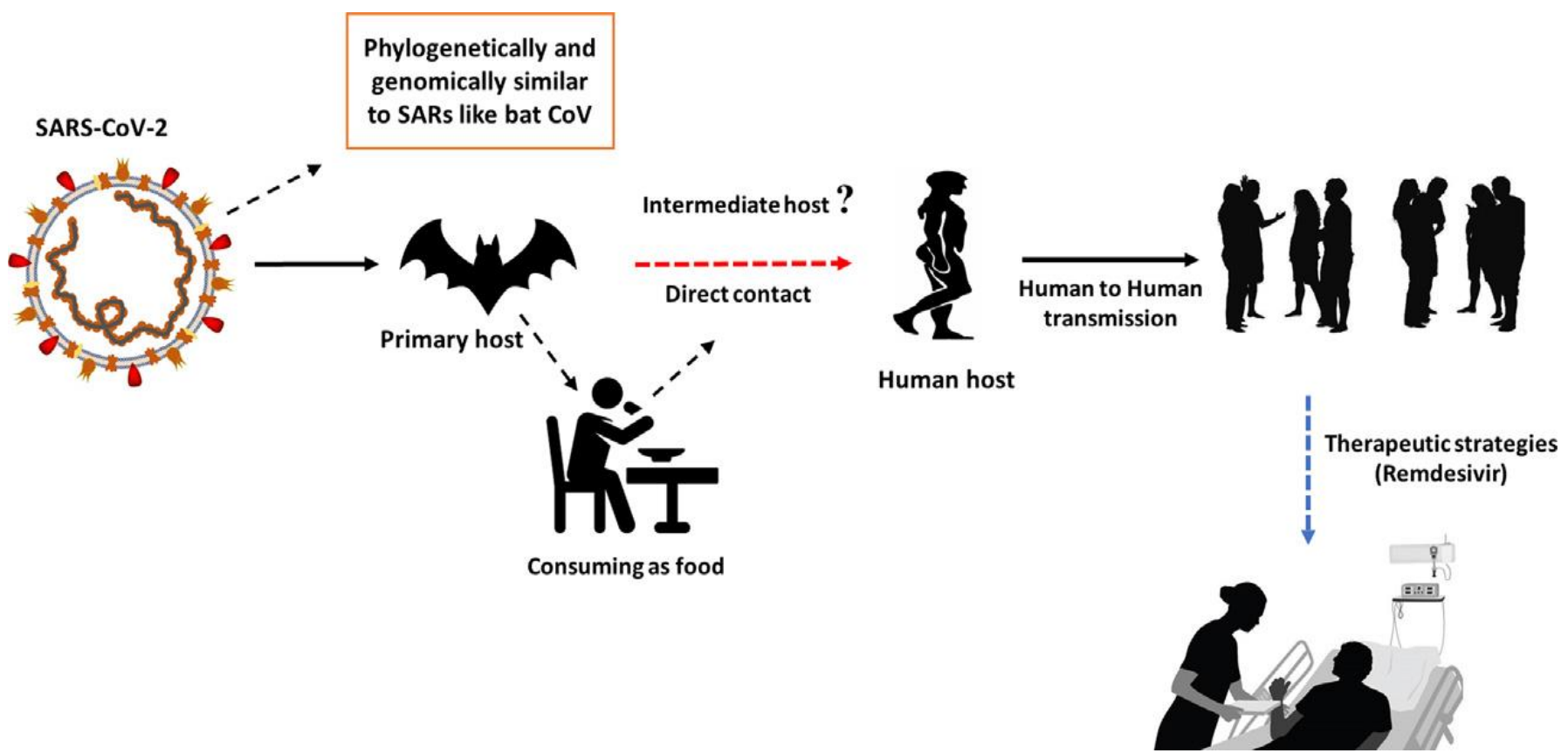

Figure 1: Mode of Transmission of Severe Acute Respiratory Syndrome Coronavirus 2 (SARS-CoV-2) [4].

\subsection{Review of Body's Temperature in Relation to Covid-19}

A rise in normal human body temperature is an early warning sign of infection. Fever is one of the body's first reaction to infection and is common in illnesses like influenza and COVID-19. According to the world health organization (WHO), $87.9 \%$ of 55,924 laboratoryconfirmed cases reported a fever. Monitoring the body temperature, even when a worker is healthy, can help detect disease early and also help the worker know if it's okay to go to work.

Part of the worker's brain called the hypothalamus continually adjusts the personnel's body temperature to maintain an optimal environment for the worker's body functions. Body temperatures vary with gender, age, overall health, and environmental factors. A generally medically accepted normal body temperature ranges between 36.5 degree Celsius (97.7 degreeFahrenheit) to 37.5 degree Celsius (99.5degree Fahrenheit).

When the personnel's immune system detects the presence of a virus in the body, it signals the hypothalamus to turn up the heat, creating a fever, a hot and hostile environment that weakens the virus and stimulates the personnel's immune response. A temperature higher than 38 degree Celsius (100.4 degrees Fahrenheit) most often indicates that the body is fighting an infection. By regularly monitoring the personnel's body temperature and learning what is normal for him, company's management can immediately detect subtly higher temperatures. This might be an early warning sign that the personnel is about to get sick, so taking immediate measures to protect others becomes an important thing to adopt. This is critical for diseases like COVID-19 where the personnel may be contagious several days before showing any symptoms at all.

\subsection{African Covid-19 Cases}

Recently, in Africa, WHO reported that there were about 1201111 confirmed cases of corona virus with over with 26475 deaths. It was reported that the majority of the death in one of the regions like Nigeria, for instance, was about 4.2\% (1 113) confirmed cases [8]. Following these reports, the Nigerian government instituted measures to contain the virus including closure of schools which has caused serious disorganization in the system. Opening of schools in Nigeria pose serious challenges considering the inability of the government to contain the spread of the virus.

In most African academic institutions like, local schools, there are lack of basic infrastructure and social amenities like classrooms/spaces, conducive learning environment, water, sanitation and hygiene. The government has not demonstrated enough serious commitment on how schools will manage COVID-19 upon resumption of academic activities. There could be vulnerability of children to contacting COVID-19 more easily, given that they may not be able to adhere to the restricted measures like wearing of mask, washing and sanitizing of hands as stated by NCDC remains a source of concern and worrisome. These concerns are already raising a lot of issues including expressions in social media about the danger of reopening of schools with many expressing fear and anxiety over school resumption. 
Currently, there are paucity of interventions that focus on anti-COVID-19 automatic technologies, such as automatic human body sanitizer, digital remote surveillance, monitoring and recording in Nigeria. Given the misconceptions, inadequate sanitation and hygiene in Nigeria, there is need for anti-COVID-19 project which is geared towards the prevention, reduction and containment of COVID-19 pandemic.

\subsection{The Consequential Effects of Covid-19 \\ Pandemic}

There are several ways through which the spread of COVID-19 pandemic or any other outbreak of infectious disease can affect the whole activities across the whole world [2]. These consequential effects could be political, economic, sociological, physiological, and psychological effect.

\subsubsection{Political effect}

The Covid-19 pandemic has had major consequential effects on the political activities. Policy makers have found it very high profile challenging in decisions and policy making as the end re-opening of the economy as the virus spread surges across the globe. The governments are punished in terms of political approval when Covid-19 infections accelerate, particularly in the absence of effective lockdown measures and as well as politicizing in the media [9]. Economic indicators, in contrast, do not appear to be strong predictor of political approval rates during this crisis.

\subsubsection{Economic effect}

With urbanization, globalization and climatic change, the outbreaks of infectious disease outbreaks and pandemic have become threats across the globe requiring a collective response against a common enemy - an enemy against humanity [10]. For the past few months, the global economy has been unable to resist the turmoil cursed by the surge of COVID-19 outbreak [11]. Firstly, inadequacy in technical and medical facilities to curtail the spread of the virus has resulted to its contagious nature and made people to physically distance themselves from one another which led to the closure of financial commerce, corporate affairs, small, medium, and large businesses and events [2][12]. Secondly, the exponential rate at which COVID-19 was surging, caused the greatest collapse in global economic activities. Thirdly, the virus crises has heightened uncertainty about how worse situation of things could get in the post-pandemic as a result of high levels of public indebtedness by emerging economy in low and middle economy countries [13].

Furthermore, The spread of the virus led to flight to safety in investment and consumption among consumers, manufacturers, and international trade cooperators [12].

\subsubsection{Sociological effect}

Before the eruption of the spread of the virus, the globe was known to socially interact physically, but today, it is a different thing. In an approach to curtail the virus, the whole world finds it difficult to physically come together in usual manner to interact, strategize, and dialogue on the way forward. This, therefore, has resulted to national and international conflicts as the case may be and has negatively impacted achievements in the shortand medium-term occasions.

\subsubsection{Psychological effect of Covid-19}

Recently, people's ways and psychology over life have been exponentially affected as a result of the spread of the pandemic. The challenge to psychological resilience is so eminent that the first and second wave of the outbreak of COVID-19 has surgically led to anxiety, depression, stress, and any other form of psychiatric symptoms [14].

\subsection{Mitigation Measures}

In response to eradicating COVID-19, a lot of responsive actions like; the use of face shields, surgical masks, strict restriction of the movement, social and physical distancing were adopted to slow the spread of the virus [15]. Centers for Disease Control and Prevention (CDC) engaged in a lot of active responses to stop the spread of the virus [16][17].

Other preventive measures have been strategically adopted to currently slow the spread of the virus. Early screening examination, training of medical workers, proper diagnosis, quarantine, and the early treatment of those diagnosed with COVID-19 are essential to mitigate further spread of the disease. Mitigation strategies are focused on the quarantine of patients and people the patients made contact with, then, followed by careful control of the infection, including appropriate strategic measures to be used during the diagnosis and the provision of medical care to an infected person [18][19]. The government and clinical workers have encouraged the (a) closure of civic centres, educational institutions, worship centres, and workplaces, (b) respirators, face masks, and face shields, (c) Limiting the number of visitors and physical distancing as ways in which COVID-19 could be prevented, (d) Cancellation of activities as a result of close proximity, (e) restriction of cloud to gather together, (f) Compulsory quarantine of buildings or residential areas, (g) External and Internal Closures of border, (h) Stay-at-home order and movement restrictions for a given period of time [18].

However, the unprecedented threat posed by the pandemic still posed serious challenges to the policy, economy, and health of the globe. Therefore, development of modern technologies is urgently essential and needful for the diagnosis of COVID-19 challenges [20]. These constraints of the virus have caused led us in the 
development of Auto Sanitizer that can be used to disinfect human beings or an object of the virus.

\subsection{METHODOLOGY AND DEVELOPMENT AUTO-SANITIZER: \\ 2.1 Aluminum Formwork Construction}

The auto sanitizer was structurally developed with aluminum material alloy frame and composite sheets were used to construct the square tunnel shape, because of its extensive use in structural applications, owing to the fact that they have light weight, high strength, economical, and resistant to corrosion when compared to steel. Fig 2 showed typical description of aluminum framework as stated by Deshmukh, et al [21].

\section{Wall/Vertical $\square$ Framework Reinforcemen \\ Erection}

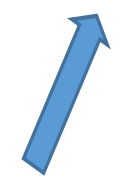

De-shuttering glab \&

Beam Panels

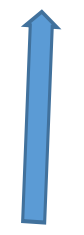

De-shuttering

Vertical Framework

\section{Electrical Work}

\section{Slab Reinforcement}

Figure 2: Description of Aluminum Framework Construction.

\subsection{Production Procedure of Sanitizing Fluid}

i. $\quad 30 \mathrm{ml}$ of glycerol $98 \%$ was measured into a $50 \mathrm{ml}$ measuring cylinder and the volume reading was taken by placing the eye level with the meniscus and reading off the value at the base of the meniscus.

ii. $\quad 83 \mathrm{ml}$ of hydrogen peroxide $3 \%$ was measured into a $50 \mathrm{ml}$ measuring cylinder and the reading was taken in the same way as the glycerol.

iii. $384 \mathrm{ml}$ of distilled water was measured into a $500 \mathrm{ml}$ measuring beaker.

iv. $1503 \mathrm{ml}$ of isopropanol $99.8 \%$ was measured into a $2 \mathrm{~L}$ measuring cylinder.

v. Into a clean container, the measured quantities of glycerol 98\%, hydrogen peroxide 3\%, distilled water and isopropanol $99.8 \%$ was added accordingly and mixed to homogenize by shaking for 5 mins.

\subsection{RESULTS}

\subsection{Functional Process of Solar Powered} Aluminum Structural Chamber

The Aluminum Structural chamber was constructed and powered with sustainable and renewable energy. The Solar panel was made up of arrays of photovoltaic cells (also called solar cells), connected to deliver rated voltage and power. The solar panel was of high efficiency monocrystalline cells with anti-reflective coating. The module was weatherproof, and its front was of high strength tempered glass with lightweight aluminum and pre-drilled mounting holes frames. The solar module was of $12 \mathrm{v}$ nominal operating voltage and matched electrically to assure good power output to the whole system. The solar module was equipped with devices like diodes for protection against reverse flow current into solar module. The solar module was with double back sheet for the protection from scratching, cuts, breakage, and other environmental conditions. The solar Inverter converted DC Power generated by Solar Panels into AC Power which was used to power up the system and was compatible with grid-supplied electricity (voltage and frequency). The inverter also ensured that the Solar Panel was generating maximum power possible under given sunlight conditions.

The Inverter was also capable of monitoring various parameters which indicate the health of the whole system, allowing us to analyze trends and performance of the solar plant. The most important task of an inverter, however, was to produce AC power of right voltage and frequency, as well as synchronize with the grid-supplied power for seamless usage of solar power being generated.

The charge controller consisted of the following features: boost, equalize and float charging of batteries was programmed to temperature compensated regulation voltages. It had a comprehensive metering, built in Alphanumeric LCD display on the front, Built-in test programs for low maintenance batteries for auto calibration, testing, measuring and calculating parameters. The charge controller had lightening protection and overload protection.

The Auto Sanitizer has an installed Bluetooth infrared thermometer and the body temperature readings that were viewed via an Android Cell phone when human body was close proximity with it. For best results, each reading of the body temperature was based on ensuring that personnel avoided eating or drinking anything hot or cold for at least 15 minutes beforehand, and not checking the temperature immediately after exercising which is an ideal practice. The structural chamber has a sensor that triggered the pump to spray sanitizing fluid on surfaces which acted like a coating barrier against infectious disease. The system was also incorporated with CCTV for monitoring. 


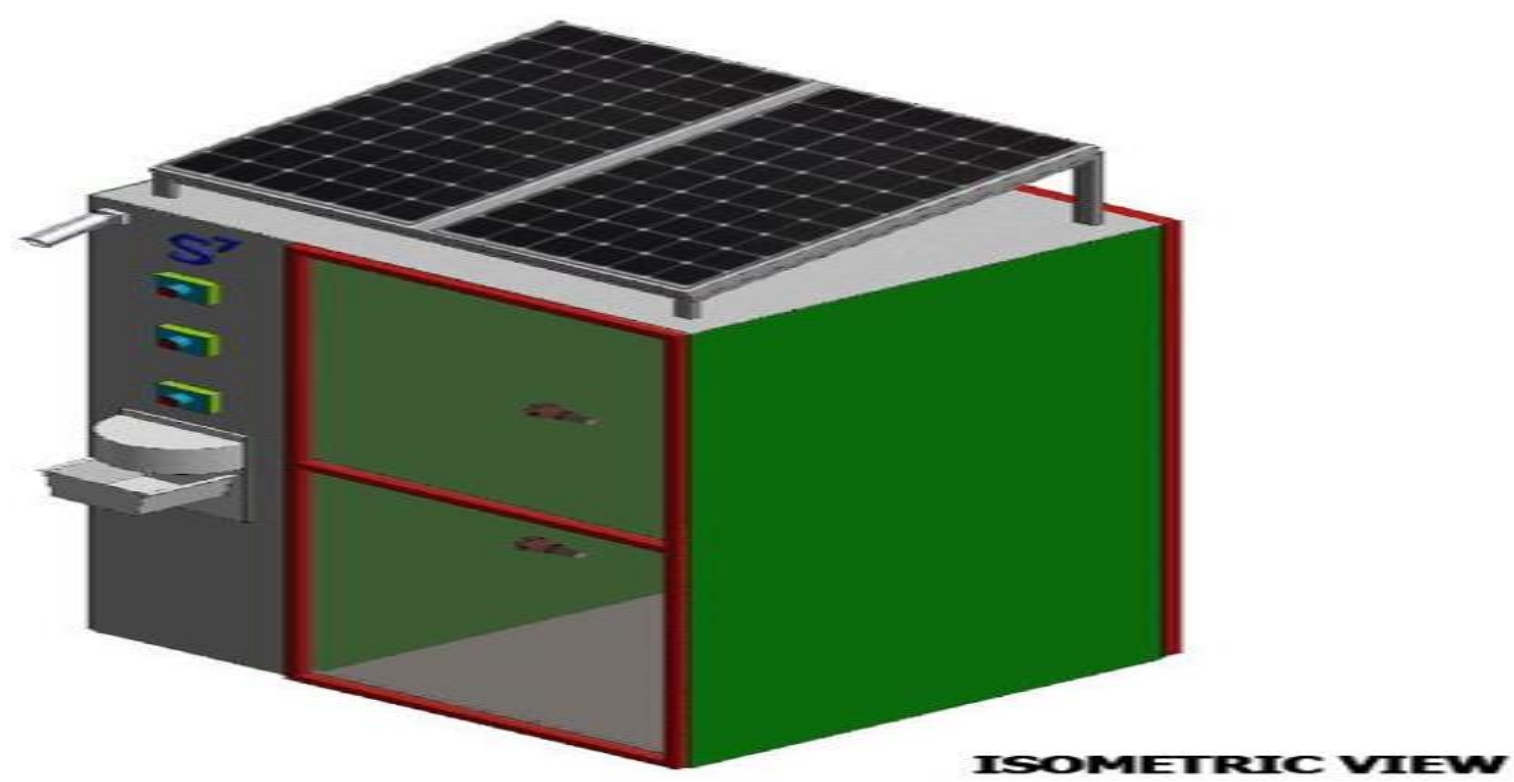

Figure 3: Isometric view of the solar powered aluminum chamber disinfectant.

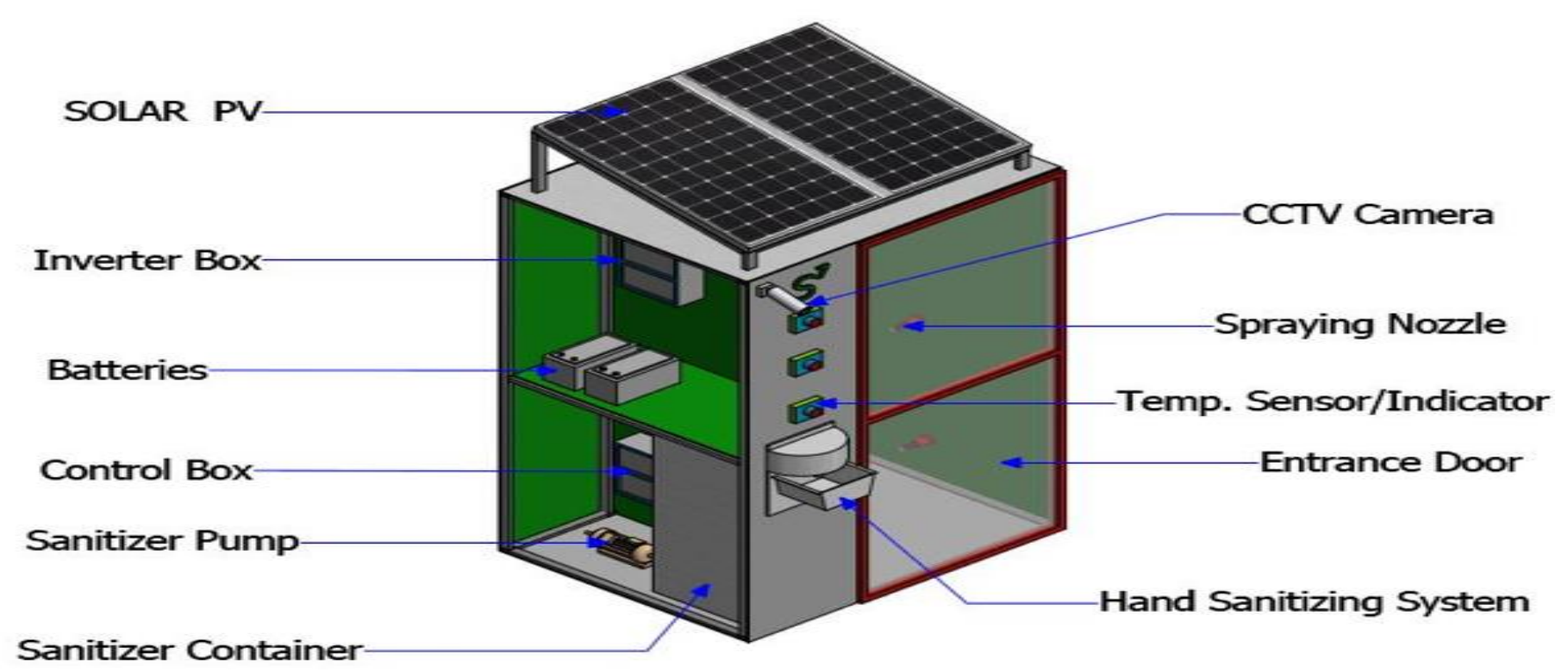

Figure 4: Annoted view of the solar powered aluminum chamber disinfectant.
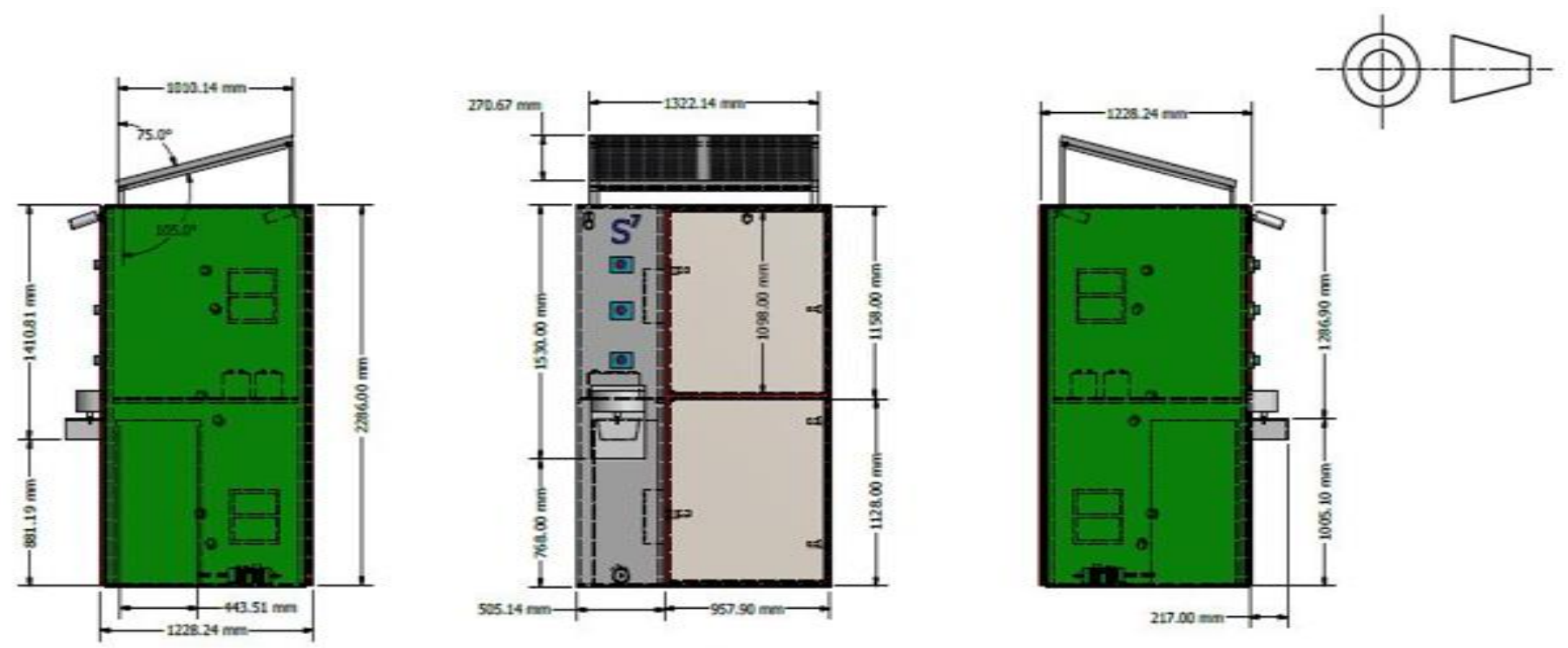

Figure 5: Orthographic projection of the solar powered aluminum chamber disinfectant. 

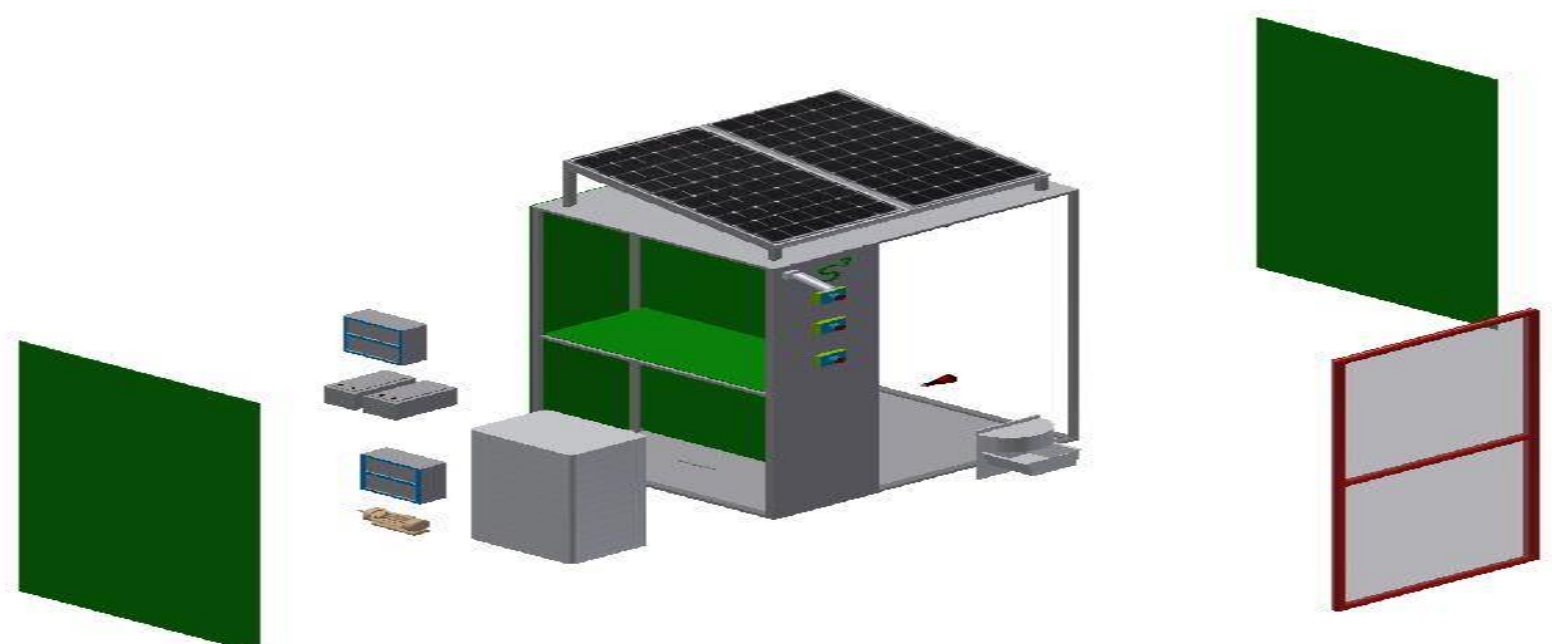

Figure 6: Component descriptive diagram of the solar powered aluminum chamber disinfectant.

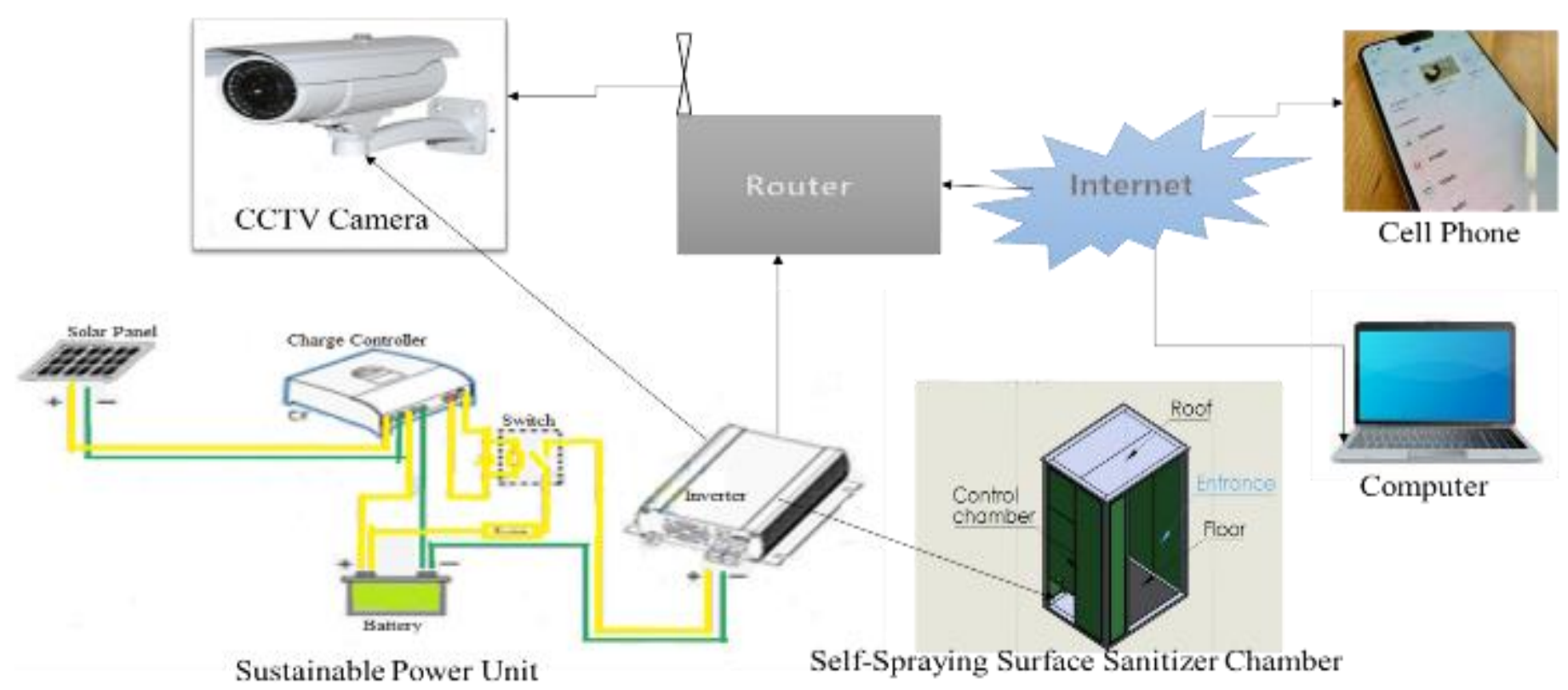

Figure 7: Descriptive diagram of the conceptual connections of other gadgets to the aluminum chamber.

\subsection{Installation and Connections of Electrical Gradients}

A pump was installed on the unit. It has a voltage of $\mathrm{DC} 12 \mathrm{~V}$, a power of $60 \mathrm{~W}$, a pressure of $0.8 \mathrm{Mpa}$, and a flow rate of $5 \mathrm{~L} / \mathrm{min}$. High-pressure pipe, reducers, connectors, and nozzles were connected to the device. Solar PV of 160watts was installed and connected to charge the battery of $120 \mathrm{Amps} / \mathrm{hr}$. The charging of the battery was regulated with charge controller. Motion sensor switch was also connected to trigger the pump. The $\mathrm{DC}$ was converted to $\mathrm{AC}$ with the use of inverter.

Table 1: WHO formulation for 2litres of sanitizer solution.

\begin{tabular}{lll}
\hline Reagents & Final concentrations (\% vol/vol) & Quantities of reagents (mL) \\
\hline Isopropanol 99.8\% & $75 \%$ & $1503 \mathrm{~mL}$ \\
Glycerol 98\% & $1.45 \%$ & $30 \mathrm{~mL}$ \\
Hydrogen peroxide 3\% & $0.125 \%$ & $83 \mathrm{~mL}$ \\
Distilled water & q.s & q.s \\
\hline
\end{tabular}

\subsection{DISCUSSION}

Our developed auto-sanitizer was able to be powered with solar energy which is highly sustainable when there was no usual electric power from national transmission grid. The total power consumption of the whole system was $76 \mathrm{~W}$. The developed system effectively 
discharged skin friendly sanitizing fluid solution at the rate of 0.083 litre per second and only needed to spray on the surface for 10 seconds.

The thermometer and CCTV that were connected to the auto-sanitizer respectively checked the individual body temperature and enabled proper monitoring of the system usage by the people entering and leaving the vicinity where it was located.

Therefore, the development and use of autosanitizer for the prevention of COVID-19 pandemic has demonstrated effective mitigation strategies which are one of the essential keys to staying healthier and happier.

Other strategies are the advocacy for personal sanitation and hygiene, sensitization and monitoring campaigns through the use of CCTV and media about COVID-19 has led to behavioural change which resulted to improved health outcome among school children, teachers, and the community at large. Because of the stakeholders' engagement and other advocacy plans, the proposed project impacted policies that lead to risk reduction and safety of children in schools.

Lastly, it is expected that there will be largely improved health and well-being of the society if and only if other COVID-19 mitigation measures are strictly adopted and adhered by all and sundry.

\subsection{CONCLUSION}

The outbreak of COVID-19 has spontaneously led to the adaptation modern technological devices that are needful for prevention and eradication of contagious diseases and reverse the global socio-economic status for better. It has also, increased appreciation of modern-day technology as a means of solving societal problems like that of the unprecedented novel coranavirus pandemic.

Our anti-COVID-19 research generated enough information that equipped an active constituency of local people, implementers and stakeholders with the evidence and knowledge they needed for the mitigation of risk of contracting COVID-19.

\subsection{RECOMMENDATION}

Everyone needs to take absolute mitigation measures against the surge of the novel coronavirus pandemic which has widely ravaged the health and economy of the globe.

\section{ACKNOWLEDGEMENT}

The authors wish to appreciate the support and the facilitating environment provided by the African Centre of Excellence for Sustainable Power and Energy Development (ACE-SPED), University of Nigeria, Nsukka that enhance the completion of this research.

\section{REFERENCES}

[1] WHO, "WHO siterep 73," World Heal. Organ., (2019), 2633, 2020.
[2] Isukul, A., Chizea, J. and Tobin, V. "Covid-19: Socio-Economic Implications and Effect of Government Policy Initiatives on Developing Economies Covid-19: Socio-Economic Implications and Effect of Government Policy Initiatives on Developing Economies," (2020).

[3] Ouassou, H., Kharchoufa, L., Bouhrim, M., Daoudi, N.E., Imtara, H., Bencheikh, N., ELbouzidi, A. and Bnouham, M. "The Pathogenesis of Coronavirus Disease 2019 (COVID-19): Evaluation and Prevention," Journal of immunology research, (2020).

[4] Shereen, M.A., Khan, S., Kazmi, A., Bashir, N. and Siddique, R. "COVID-19 infection: Origin, transmission, and characteristics of human coronaviruses," Journal of advanced research, 24 (2020), 91-98.

[5] Ngwewondo, A., Nkengazong, L., Ambe, L.A., Ebogo, J.T., Mba, F.M., Goni, H.O., Nyunai, N., Ngonde, M.C. and Oyono, J.L.E. "Knowledge, attitudes, practices of/towards COVID 19 preventive measures and symptoms: A crosssectional study during the exponential rise of the outbreak in Cameroon," PLoS neglected tropical diseases 14(9), (2020), 1-15.

[6] Coppin, J.D., Villamaria, F.C., Williams, M.D., Copeland, L.A., Zeber, J.E. and Jinadatha, C. "American Journal of Infection Control Selfsanitizing copper-impregnated surfaces for bioburden reduction in patient rooms," American journal of infection control 45(6), (2017), 692694.

[7] Echtioui, A., Zouch, W., Ghorbel, M., Mhiri, C. and Hamam, H. "Detection Methods of COVID19," Translating Life Sciences Innovation, 25(6), (2020), 566-572.

[8] WHO, "COVID-19 situational update report 32 for the world african region 7 october 2020," (2020), 1-9.

[9] Har, P.S., Chinn, S. and Hart, P.S. "Politicization and Polarization in COVID-19 News Coverage," Science Communication, 42(5), (2020) 679-697.

[10] Pak, A., Adegboye, O.A., Adekunle, A.I., Rahman, K.M., McBryde, E.S. and Eisen, D.P. "Economic Consequences of the COVID-19 Outbreak: the Need for Epidemic Preparedness," Frontiers in public health 8 (2020), 241.

[11] Sikder, M., Zhang, W. and Ahmod, U. "The Consequential Impact of the Covid-19 Pandemic on Global Emerging Economy," American Journal of Economics 10(6), (2020), 325-331.

[12] Ozili, P.K. and Arun, T. "Spillover of COVID-19: Impact on the Global Economy," SSRN Electron. Journal, 3562570, (2020).

[13] McKibbin, W. and Vines, D. "Global macroeconomic cooperation in response to the 
COVID-19 pandemic: A roadmap for the G20 and the IMF," Oxford Review of Economic Policy 36(Supplement_1), (2020), S297-S337.

[14] Mustafa, N. "Psychological Stress and Associated Factors during the Coronavirus Disease ( COVID19 )," International Journal of Science and Research 10(4), (2020), 12-18

[15] Switzer, D., Wang, W. and Hirschvogel, L. "Municipal Utilities and COVID-19: Challenges, Responses, and Collaboration," The American Review of Public Administration, 50(6-7), (2020), 577-583.

[16] Kirlin, J. "COVID-19 Upends Pandemic Plan," The American Review of Public Administration, 50(6-7), (2020), 467-479.

[17] Reuschke, D. and Felstead, A. "Changing workplace geographies in the COVID-19 crisis," Dialogues in Human Geography, 10(2), (2020), 208-212.
[18] Güner, H.R., Hasanoğlu, İ. and Aktaş, F. "Covid19: Prevention and control measures in community," Turkish Journal of medical sciences 50(SI-1), (2020), 571-577.

[19] Zhang, N., Shi, T., Zhong, H. and Guo, Y. "Covid19 prevention and control public health strategies in shanghai, china," Journal of Public Health Management and Practice, 26(4), (2020), 334-344

[20] Guan, W.J., Chen, R.C. and Zhong, N.S. "Strategies for the prevention and management of coronavirus disease 2019," European Respiratory Journal, 55(4), (2020), 8-11.

[21] Deshmukh, A.S. and Shalgar, M.A., "Study of Tunnel Formwork versus Aluminium Formwork," International Research Journal of Engineering and Technology (IRJET) 3.12 (2016): 477-480. 3(12), (2016), 477-480. 